\title{
ПЕДАГОГІЧНІ УМОВИ ФОРМУВАННЯ ГЕНДЕРНОЇ КОМПЕТЕНТНОСТІ МАЙБУТНІХ УЧИТЕЛІВ
}

\author{
Ремньова А. $\Gamma$. \\ кандидат педагогічних наук, \\ старший викладач кафедри теорії та історії педагогіки \\ Національний педагогічний університет імені М. П. Драгоманова \\ вул. Пирогова, 9, Київ, Украӥна \\ orcid.org/0000-0001-9705-036X \\ lika.remm@gmail.com
}

\author{
Ключові слова: \\ гендер, гендерна \\ компетентність, гендерний \\ підхід, педагогічні умови, \\ майбутні вчителі.
}

Стаття присвячена одній із актуальних проблем підготовки майбутніх учителів - формуванню гендерної компетентності, яка $є$ важливим складником їхньої професійної підготовки. Подано короткий аналіз наукових досліджень щодо проблеми впровадження гендерного підходу в систему освіти й гендерного виховання учнівської молоді. Окреслено коло проблем 3 гендерної проблематики, які $\epsilon$ предметом наукових пошуків вітчизняних учених.

У статті проаналізовано сутність понять «гендер» i «гендерна компетентність» із різних наукових позицій, акцентовано увагу на психолого-педагогічних аспектах цих категорій. Підкреслено, що поняття «гендер»є соціально-демографічною категорією, яка з'явилася для визначення саме соціальних, а не біологічних відмінностей між чоловіками і жінками. Доведено, що подолання гендерних стереотипів у майбутніх учителів і в учнів сприятиме вихованню моральних норм рівності, рівноправності, поваги до осіб як жіночої, так і чоловічої статі, формуванню вільної особистості.

Досліджено сутнісні характеристики поняття «гендерна компетентність», обгрунтовано думку, що оволодіння гендерною компетентністю $\epsilon$ не тільки однією з умов успішної соціалізації особистості, а й умовою професійного розвитку майбутнього вчителя. Проаналізовано структуру гендерної компетентності майбутніх учителів, яка складається з чотирьох компонентів: когнітивного, емоційно-ціннісного, мотиваційного, організаційно-технологічного.

Подано аналіз результатів дослідження щодо сформованості гендерної компетентності в студентів 1-2-х курсів НПУ імені М.П. Драгоманова відповідно до визначених компонентів.

Обгрунтовано педагогічні умови формування гендерної компетентності майбутніх педагогів, які дадуть їм змогу не тільки поглибити теоретичні знання 3 гендерної проблематики, а й здійснювати аналіз гендерних проблем і сформувати практичні навички й уміння організації освітнього процесу на засадах гендерної рівності. Упровадження зазначених педагогічних умов у підготовку майбутніх учителів сприятиме розвитку їхньої професійної майстерності. 


\title{
PEDAGOGICAL CONDITIONS OF FUTURE TEACHERS' GENDER COMPETENCE FORMATION
}

\author{
Remnova A. G. \\ Candidate of Pedagogical Sciences, \\ Assistant Professor at the Department of Theory and History of Pedagogy \\ Dragomanov National Pedagogical University \\ Pyrohova str., 8, Kyiv, Ukraine \\ orcid.org/0000-0001-9705-036X \\ lika.remm@gmail.com
}

Key words:

gender, gender competency, gender approach, pedagogical conditions, future teachers.
This article is dedicated to one of the actual problems of young teachers' education-gender competence formation, which is an important component of their professional education. It lays out a brief analysis of scientific research on the implementation of gender approach into the educational system and gender upbringing of studying youth. The article defines a number of gender problems, which are a subject to scientific research of Ukrainian scholars.

It analyses the essence of "gender" and "gender competency" notions according to various scientific views and emphasises on psychological and pedagogical aspects of these categories. It is pointed out that "gender" notion is a socio-demographic category, emerged in order to define sociological, but not the biological differences between men and women. It's proved that overcoming gender stereotypes among future teachers and students will contribute to moral standards of equality, equal rights, respect to both men and women, free personality formation.

The article examines essential characteristics of the "gender competency" notion, substantiates the idea that mastering gender competency is not only one of individual's successful socialisation conditions, but also is a condition of future teacher's professional development. It analyses the structure of future teachers gender competency, which consists of 4 elements: cognitive, emotions and values element, motivational, organisation and technology element.

This article provides an analysis of the research results on gender competency formation of the first and second year students of the Dragomanov National Pedagogical University according to the defined components.

It also interprets pedagogical conditions of future teachers gender competency formation, which not only allow them to deepen their theoretical knowledge on gender problems, but also conduct gender problems analysis and form practical skills and ability to organise educational process on gender equality basis. Implementation of pedagogical conditions mentioned above will contribute to their professional excellence.
Постановка проблеми. Зміни, що пережило українське суспільство в останні десятиліття, вплинули не тільки на свідомість українців, а й на погляди вчених у галузі педагогіки та виховання й вимагають їх осмислення та поступового перекладу мовою освітньої політики. Інтеграція України в європейський освітній простір потребує переоцінки базових традиційних цінностей, зокрема таких, що пов'язані із соціорольовою поведінкою членів суспільства. Соціальне замовлення викликає необхідність формування гендерного світогляду в підростаючого покоління, що сприятиме подоланню гендерних сте- реотипів в учнів, вихованню моральних норм рівності, рівноправності, поваги до осіб як жіночої, так і чоловічої статі, формуванню вільної особистості.

Необхідність упровадження гендерного підходу в педагогічну освіту, формування гендерної культури в учнівської молоді викликано не тільки демократизацією українського суспільства, а й деякими негативними тенденціями: лібералізацією статевої моралі, послабленням сімейної виховної функції, украй повільними темпами розроблення освітніх програм гендерного виховання. Гендерний підхід в освітньому процесі зміг би 
розширити життєвий простір кожного вихованця для розвитку його індивідуальних здібностей i задатків, а для педагогів був би корисним тим, що звільнив їхнє мислення від усталених статево-рольових стереотипів.

Метою сучасної системи виховання є формування різнобічно розвиненої, морально зрілої, творчої особистості. Отже, для підростаючого покоління знання про взаємини жінок і чоловіків - актуальні та важливі. Це підтверджує низка нормативно-правових документів України найвищого державного рівня, у яких відображені основні напрями модернізації системи національної освіти стосовно гендерного виховання (Закон України «Про забезпечення рівних прав та можливостей жінок і чоловіків» 2005 року; Постанова Кабінету Міністрів України «Про затвердження Державної програми 3 утвердження гендерної рівності в українському суспільстві на період до 2010 року» від 27.12.2006 № 1834; Наказ МОН України «Про впровадження принципів гендерної рівності в освіту» від 10.09.2009 № 839; Розпорядження Кабінету Міністрів України «Стратегія упровадження гендерної рівності та недискримінації у сфері освіти «Освіта: гендерний вимір2021» від 17.01.2016; Національна стратегія розвитку освіти в Україні на 2012-2021 роки). Ці документи визначають завдання підготовки навчальних програм, підручників і посібників для закладів загальної середньої освіти з урахуванням гендерного підходу, виховання хлопчиків і дівчат у дусі поваги до прав і можливостей статі й вільного волевиявлення особи та скеровують заклади вищої освіти до оновлення освітніх програм 3 огляду на формування гендерного світогляду майбутніх фахівців. Тому формування гендерної компетентності майбутніх учителів, підготовка їх до реалізації гендерного виховання школярів нині $є$ актуальною та своєчасною науково-педагогічною проблемою.

Аналіз останніх досліджень. Зацікавленість сучасних дослідників проблемою впровадження комплексного гендерного підходу в систему освіти учнівської молоді зумовила появу низки науково-педагогічних досліджень, серед яких, зокрема, порушена проблема формування гендерної компетентності майбутніх учителів.

Необхідність підготовки майбутніх учителів до гендерного виховання учнівської молоді доведена в працях І. Бондаревської, В. Гайденко, Г. Лактіонової, О. Любарської, І. Предборської, С. Юдіної. Різноманітним аспектам гендерної педагогіки, гендерного виховання та загальної теорії гендеру в освіті присвячені праці Л. Вовк, С. Вихор, Т. Говорун, Т. Дороніної, В. Сремеєва, І. Іванової, О. Кікінеджі, В. Кравця, І. Мунтяна, Н. Павлущенко, О. Цокур, Л. Штильової.
Проблема гендерного виховання відображена в численних психолого-педагогічних дослідженнях Т. Бендас, Ш. Берн, Т. Говорун, О. Кікінеджі, І. Кльоціної та інших. Сутність і зміст гендерної компетентності особистості та шляхи іiі формування в контексті професійної підготовки майбутніх фахівців досліджували В. Агєєва, Л. Вовк, О. Горошко, І. Кльоціна, І. Таліна, О. Кіріленко, Н. Лавриненко, О. Луценко, Л. Міщик, І. Харченко.

Аналіз науково-теоретичної та методичної літератури, нормативних документів i практичних наробок свідчить про певний накопичений досвід реалізації комплексного гендерного підходу в освіті. Водночас динамічність змін у сучасному суспільстві, постійні виклики у сфері освіти потребують оновленого осмислення всіх аспектів проблеми формування гендерної компетентності майбутніх вчителів.

Мета дослідження. Актуальність заявленої проблеми й об'єктивна потреба у створенні системи підготовки майбутніх учителів до формування гендерної компетентності зумовили мету дослідження, яка полягає у визначенні змісту i структури гендерної компетентності майбутніх учителів та в обгрунтуванні педагогічних умов ii формування в освітньому просторі закладів вищої освіти.

Виклад основного матеріалу дослідження. Розглянемо та проаналізуємо головні категорії дослідження - «гендер» і «гендерна компетентність». Історія появи в загальнолюдській культурі поняття «гендер» пов'язана 3 розвитком теоретичних засад фемінізму та 3 дослідженнями американського психоаналітика Р. Столлера, який у 1968 році видав наукову працю під назвою «Стать та гендер: про розвиток мужності та жіночності» [1]. Цей термін почали вживати в дослідженнях інші зарубіжні філософи, зокрема А. Річ [2], Р. Унгер [3], Г. Рубін [4]. Відповідно, на початку 80-х років XX століття з'являється нова галузь гуманітарного знання - гендерні дослідження, які сконцентрували й звели в систему наукові погляди щодо соціального статусу та ролі жінок і чоловіків у суспільстві, їхніх характеристик та особливостей.

Термін «гендер» («gender») дослівно перекладається 3 англійської як «рід» (але тільки в лінгвістичному значенні цього слова - «рід іменника»). 3 філософського погляду «гендер» $\epsilon$ науковою дефініцією, яка визначає соціально-культурні функції статі й дає змогу відрізняти ці функції від біологічних, а також від біологічної статі (в англійській мові - sex). Філософи-феміністки та американські теоретики теорії сексуальності надали терміну «гендер» однозначно соціального забарвлення, зокрема Г. Рубін - американська 
антропологиня, теоретикиня у сфері гендерної та сексуальної політики - у праці «Обмін жінками» чітко визначила термінологічну відмінність між поняттями «гендер» і «стать» [4]. Тому поняття «гендер» почали використовувати для класифікації соціальних, а не біологічних відмінностей між жінками і чоловіками.

Сучасні дослідники аналізують сутність поняття «гендер» із різних позицій, виокремлюючи філософські, правові, соціальні, культурні й психолого-педагогічні аспекти, що формують риси, норми, стереотипи поведінки чоловіків і жінок.

Підходи до аналізу сутності цієї дефініції вражають своєю різноманітністю, адже науковці розкривають «гендер» так:

1. Окремий складник соціальної структури суспільства, який спільно 3 іншими складниками - культурними, соціальними, демографічними характеристиками, такими як раса, вік, клас тощо, утворює соціальну систему.

2. Статус, що дає змогу реалізувати соціальні можливості як чоловічої, так і жіночої статі в професійній діяльності, в освіті, у доступі до влади, у сімейній ролі та репродуктивній поведінці.

3. Модель організованих соціальних взаємин між особами чоловічої та жіночої статі, що не лише характеризує їхню взаємодію в сім’ї, особливості спілкування, а й визначає їхню соціальну роль в інституціях суспільства.

4. Процес у суспільстві, що передбачає на основі консенсусу для чоловіків і жінок справедливий розподіл соціальних умов і рівних можливостей для реалізації ними громадянських прав, для самореалізації власної особистості.

5. Певний соціокультурний конструкт, який визнає розходження чи відмінності в емоційних i ментальних характеристиках, поведінці, ролях між жінками і чоловіками, що конструюються нашим суспільством.

Узагальнюючи різні варіанти підходів до розуміння сутності терміна «гендер», ми слідом за зарубіжними вченими будемо розглядати це поняття як ключову соціально-демографічну категорію, яка фіксує диференційованих представників жінок і чоловіків. Отже, поняття «гендер» 3'явилося для визначення саме соціальних, a не біологічних відмінностей між чоловіками i жінками, суспільство змінило біологічну сексуальність у продукт активності людства.

Аналіз праць вітчизняних авторів свідчить, що розроблення такого поняття, як «гендер», активно здійснювалася в нових соціально-історичних умовах розвитку нашого суспільства. Вивчення особливостей феномена гендеру відбулося в контексті вирішення проблем соціально-гуманітарних наук. Отже, поняття «гендер» використовується успішно в різних галузях соціально-гуманітар- ного знання. Найчастіше це поняття трактується у вітчизняній науковій літературі в значенні соціально-культурної маски статі, що обумовлює гендерний статус індивіда (на відміну від біологічної статі), котрий визначає соціальні можливості особистості в освіті, репродуктивній поведінці, сім’і, професійній діяльності, доступі до влади.

Наукові дослідження гендерної проблематики в Україні сконцентрувалися навколо різних проблем:

- розмежування праці за гендером, що призводить до переважання ролі чоловічої праці як більш вагомої, ніж праця жінок;

- економічна та соціально-політична нерівність між чоловіками і жінками, що проявляються у сферах управлінських стосунків, освіти, сфері зайнятості тощо;

- поширення та розповсюдження патріархату й маскулінського світогляду, що є фундаментом дискримінації жінок;

- соціальна незахищеність, декларативність прав і подолання стереотипів щодо жінок.

Важливо, що на почату 90-х років XX століття гендерна проблематика торкнулася всіх сфер суспільного життя в Україні, а в педагогічній науці виник новий самостійний напрям гендерних досліджень і з'явилося поняття «гендерна педагогіка».

Поява поняття «гендерна компетентність» пов'язана із запровадженням у систему освіти компетентнісного підходу, який має замінити застарілий знаннєвий підхід, оновити зміст освіти 3 огляду на формування компетентностей в особистості, щоб потім вона могла успішно реалізувати себе в житті. Закон України «Про освіту», що набув чинності у 2017 року, визначає компетентність «як динамічну комбінацію знань, умінь, навичок, способів мислення, поглядів, цінностей, інших особистих якостей, що визначає здатність особи успішно соціалізуватися, провадити професійну та/або подальшу навчальну діяльність» [5]. Отже, наявність державного замовлення на формування компетентностей учнівської молоді викликає необхідність реалізації компетентнісного підходу в освітніх закладах будь-якого рівня. Оволодіння гендерною компетентністю $є$ не тільки однією 3 умов успішної соціалізації особистості, а й умовою професійного розвитку майбутнього вчителя. Саме вчитель буде здійснювати цілеспрямований педагогічний вплив на формування гендерної свідомості учнів у закладах загальної середньої освіти, де вони починають процес соціалізації й мають певні статево-рольові стереотипи.

У науково-педагогічній літературі існують різні підходи до визначення поняття «гендерна компетентність», зміст якої трактують як інтегральну характеристику особистості, як сукупність знань, 
умінь, навичок або як процес впливів на особистість. Ми погоджуємося 3 науковою позицією О. Нежинської, яка визначає гендерну компетентність як «сукупність знань, умінь, навичок, що зумовлюють взаємодію з особами різної статі на засадах гендерної рівності та $є$ опосередкованими через індивідуально-психологічні гендерні характеристики (маскулінність/фемінність, гендерна ідентичність, гендерна роль, гендерні установки та стереотипи), які проявляються в повсякденному житті, спілкуванні й поведінці з особами різної статі» [6, с. 213]. У рамках дослідження ми будемо розглядати гендерну компетентність не тільки як одну із життєвих компетентностей, а i як компонент професіоналізму майбутнього вчителя. 3 огляду на це, варто представити структуру гендерної компетентності особистості майбутнього педагога, яка, на наш погляд, включає в себе чотири компоненти:

- когнітивний компонент - знання гендерної проблематики, концептуальних основ гендерних досліджень; знання правової бази 3 проблеми гендерної рівності й демократії; усвідомлене розуміння особливостей гендерної соціалізації та психологічних причин формування гендерних стереотипів; знання принципів, форм і методів гендерної педагогіки; знання технологій гендерного аналізу підручників і прихованих навчальних планів, усвідомлення ролі школи в процесі гендерного виховання учнів;

- емоційно-ціннісний компонент пов'язаний з усвідомленням особистісної цінності гендерних знань, толерантного ставлення до індивідуальних i психосексуальних особливостей майбутніх вихованців, здатністю адекватно сприймати, аналізувати й розуміти себе та вихованця скрізь призму статевої належності й гендерної ролі;

- мотиваційний компонент передбачає розуміння своєї професійної відповідальності як активного організатора або учасника процесу гендерної соціалізації учнівської молоді; бажання постійно вдосконалювати свої знання та вміння в процесі гендерного виховання школярів;

- організаційно-технологічний компонент включає вміння організовувати спільну пізнавальну діяльність щодо засвоєння гендерних знань учнями, здійснювати контроль гендерних стратегій поведінки, сприяти розробленню та впровадженню технологій гендерного виховання учнів.

Отже, гендерна компетентність майбутніх педагогів $є$ інтегральною характеристикою особистості, має чітку структуру необхідних і важливих компонентів, формування яких забезпечить оволодіння студентами цією важливою життєвою і професійною компетентністю. На жаль, ми виявили, що студенти педагогічних закладів вищої освіти мають не дуже високий рівень гендерної компе- тентності. А це, у свою чергу, не дасть їм змоги успішно здійснювати гендерне виховання в закладах загальної середньої освіти.

3 метою виявлення проявів гендерної компетентності майбутніх вчителів нами проведено опитування 230 студентів 1-2-х курсів Національного педагогічного університету імені М.П. Драгоманова (факультет спеціальної та інклюзивної освіти; факультет педагогіки і психології; історичний факультет). Результати дослідження показали, що високий рівень знань гендерної проблематики (когнітивний компонент) мають 187 респондентів, середній -23 , низький -20 . Високий рівень усвідомлення особистісної цінності гендерних знань, толерантного ставлення до індивідуальних i психосексуальних особливостей майбутніх вихованців (емоційно-ціннісний компонент) мають 128 респондентів, середній рівень - 54, низький -48 . Високий рівень розуміння власної професійної відповідальності в процесі гендерної соціалізації учнівської молоді та бажання вдосконалювати свої знання й уміння щодо гендерного виховання учнів (мотиваційний компонент) мають 134 респонденти; середній рівень - у 63; низький рівень - 33. Щодо останнього компонента гендерної компетентності майбутніх учителів (організаційно-технологічного), то результати опитування показали, що високий рівень мають лише 38 студентів, середній - 105, низький - 87.

Аналіз отриманих результатів свідчить про те, що рівень теоретичної підготовки майбутніх педагогів до поширення гендерних знань серед вихованців значно вищий, ніж рівень практичних навичок і вмінь організації освітнього процесу на засадах гендерної рівності й упровадження технологій гендерного виховання школярів. У зв'язку з цим проблема пошуку оптимальних умов формування гендерної компетентності майбутніх учителів у процесі їхньої професійної підготовки продовжує залишатися актуальною.

Категорія «умова» $є$ загальнонауковою й уживається як у філософському, так і в педагогічному аспектах. У загальному аспекті під умовами науковці розуміють сукупність певних причин, обставин, наявність певних об'єктів, які впливають на функціонування досліджуваного явища [7]. Ми вважаємо, що в рамках дослідження доцільно використати термін «педагогічні умови», адже саме вони конструюють систему певного педагогічного процесу й охоплюють усі його компоненти (зміст, організаційні форми, засоби, методи навчання).

Педагогічними умовами формування гендерної компетентності майбутніх учителів $\epsilon$ :

- запровадження гендерної тематики в зміст фахових і психолого-педагогічних дисциплін у процесі професійної підготовки майбутніх учите- 
лів, оновлення й розширення переліку гендерних дисциплін, спецкурсів з гендерної проблематики;

- створення інтерактивного освітнього середовища 3 метою обговорення студентами власних проблем гендерної соціалізації, формування в майбутніх педагогів усвідомлення власної гендерної ролі та індивідуального гендерного стилю поведінки в майбутній педагогічної діяльності (рольові ігри, тренінги, семінари);

- залучення студентів до пізнання гендерних характеристик індивіда методами психологічної діагностики та самодіагностики як в освітньому просторі 3ВО, так і під час виробничої практики;

- ознайомлення й опанування майбутніми вчителями методами, що допоможуть визначати стан сформованості гендерної культури учнів, проводити гендерний аналіз навчальних планів i підручників, забезпечать ефективність гендерного виховання школярів.

Реалізація першої педагогічної умови формування гендерної компетентності в майбутніх учителів передбачає створення стійкої системи знань 3 гендерних проблем, зокрема загальних обізнаність про сутність гендеру та гендерного підходу, володіння ключовими гендерними термінами, знання основ концептуальних гендерних досліджень; педагогічних - усвідомлення ролі та знання технологій реалізації гендерного підходу в освітньому процесі, знання принципів, методів, форм гендерної педагогіки, розуміння сутності гендерного виховання; психологічних - розуміння причин формування гендерних стереотипів і сутності гендерних взаємин, обізнаність із психологічними механізмами формування гендерної ідентичності й особливостями гендерної соціалізації учнівської молоді; правових - знання законів, нормативних актів, розпорядчих документів 3 проблеми гендерної рівності, щодо подолання сексизму та насильства. Гендерна система знань сприятиме формуванню світогляду особистості майбутнього вчителя, власної життєвої позиції, професійній самореалізації.

Гендерна підготовка майбутніх педагогів має здійснюватися під час опанування психолого-педагогічними дисциплінами в педагогічних ЗВО і включення в них лекційного матеріалу з гендерного виховання. Це можливо зробити, якщо в навчальний план навчальної дисципліни «Педагогіка» в розділ «Теорія виховання» ввести тему «Гендерне виховання», яка дасть змогу викладачам ознайомити студентів 3 історичними аспектами виникнення гендеру, пояснити сутність цього феномена та розглянути шляхи, методи, засоби й форми гендерного виховання школярів. Бажано ввести в навчальні плани для педагогічних факультетів спецкурси «Гендерна педагогіка», «Гендерна психологія», «Основи гендерного виховання». Не завадить також усім викладачам ЗВО провести гендерний аналіз тих дисциплін, що вони викладають.

Варто зазначити, що теоретичне підгрунтя для впровадження гендерного підходу в національну систему вищої освіти створене вже на початку XXI століття спільними зусиллями творчих українських гендерних центрів. Про це свідчить поява підручників 3 гендерної педагогіки та психології: «Гендерна психологія» (автори О. Кікінеджі, Т. Говорун) [8], «Гендерна педагогіка» (автор В. Кравець) [9], навчальної програми інтегрованого курсу для студентів 2-4-х курсів педагогічних спеціальностей «Гендерна освіта: теорія та практика» (автори В. Кравець, Т. Говорун, О. Кікінеджі), програми навчального курсу для студентів 2-го курсу педагогічних спеціальностей «Теоретико-методичні засади гендерної освіти» (автори Т. Дороніна, Т. Голованова) [10] тощо. Але розроблені програми та спецкурси 3 гендерної тематики для студентів педагогічних спеціальностей упроваджено вибірково, не в усіх закладах вищої освіти.

Оскільки однією $з$ педагогічних умов формування гендерної компетентності майбутніх учителів $\epsilon$ створення інтерактивного освітнього середовища 3 метою обговорення студентами власних проблем гендерної соціалізації, то в освітній процес закладів вищої освіти варто включити семінари, дискусії, тренінги, що не лише забезпечать здобуття гендерних знань, утілення ідей гендерної рівності у власну поведінку, а й сформують гендерні вміння та практичні навички для майбутньої професійної діяльності. Наприклад, навчально-методичні тренінги на такі теми: «Звільняємося від гендерних стереотипів», «Визначаємо власну гендерну ідентичність», «Гендерний підхід в освітньому просторі НУШ»; дискусії: «Чи існує гендерна рівність в освіті?», «Навіщо потрібна гендерна рівність чоловікам і жінкам?»; семінари на теми: «Проблеми гендерного характеру в професійній діяльності педагога», «Освітнє середовище гендерної рівності».

Такі заняття ознайомлять учасників із методами гендерного підходу в освіті, сприятимуть переосмисленню своїх позицій щодо гендерних ролей, забезпечать прийняття й розуміння студентами наявного різноманіття гендерної ідентичності, навчать організації освітнього процесу так, щоб кожна дитина усвідомлювала свої можливості та шляхи реалізації незалежно від гендерної ідентичності.

Не менш важливою педагогічною умовою $\epsilon$ залучення майбутніх учителів до пізнання гендерних характеристик індивіда методами психологічної діагностики й самодіагностики. Для іiі реалізації можна використати тематичні семінари 
і тренінги, авторські розробки практичного характеру, анкетування, тестування, опитування, що забезпечать набуття досвіду студентами у здійсненні діагностики рівня гендерної компетентності усіх суб'єктів освітнього процесу. Наприклад, опитувальники: «Методика діагностування гендерної компетентності» (О. Бондарчук); «Поширеність гендерних стереотипів» (Т. Говорун, О. Кікінеджі); опитувальник С. Бем на визначення маскулінності/фемінності (дослідження власного гендерного типу особистості) допоможуть студентам визначити рівень власної гендерної компетентності й навчать визначати стан сформованості гендерної культури учнів.

Особлива роль в опануванні майбутніми вчителями техніками гендерного виміру освітнього середовища закладу загальної середньої освіти, набутті студентами індивідуального досвіду гендерного виховання учнів має педагогічна виробнича практика. Тому викладачам варто розробляти програму практики з урахуванням гендерного складника.
Висновки та перспективи дослідження. Отже, визначені нами педагогічні умови формування гендерної компетентності майбутніх учителів, побудовані на принципах рівних можливостей, гендерної толерантності, партнерства та гармонізації соціальної й біологічної природи особистості, будуть сприяти звільненню від гендерних стереотипів, самореалізації в майбутній професійній діяльності. Наявність у майбутнього педагога гендерної компетентності забезпечить єдність цілеспрямованих дій освітнього процесу для здобувачів освіти різної статі.

Подальшого дослідження потребує проблема формування гендерної культури в різних соціальних груп населення, вивчення особливостей гендерного виховання та самовиховання в учнів різного віку, подальше розроблення відповідних методик і технологій формування гендерної компетентності в учнівської молоді, вивчення зарубіжного досвіду гендерного виховання в учнів і в майбутніх учителів.

\section{Література}

1. Stoller R. Sex and Gender: On the Development of Masculinity and Femininity. New York, 1968. 383 p.

2. Rich A. Of Women Born: Motherhood as Experience and Institution. London : Viagro, 1977. 230 p.

3. Unger R. Toward a Redefinition of Sex and Gender. American Psychologist. 1979. № 3. P. 43-57.

4. Рубин Г. Обмен женщинами: заметки о политической экономии пола : хрестоматия феминистских текстов. Переводы / под ред. Е. Здравомысловой, А. Темкиной. Санкт Петербург : Дмитрий Буланин, 2000. С. 89-139.

5. Про освіту : Закон України від 05.09.2017 № 2145-VIII. URL: http://zakon.rada.gov.ua/laws/ show/2145-19 (дата звернення: 27.08.2020).

6. Нежинська О.О. Модель гендерної компетентності керівників загальноосвітніх навчальних закладів / гол. ред. В.В. Олійник. Вісник післядипломної освіти : збірник наукових праць. Київ : Геопринт, 2008. Вип. 10. С. 212-219.

7. Литвин А. Методологічні засади поняття «педагогічні умови»: на допомогу здобувачам наукового ступеня. Львів : СПОЛОМ, 2014. 76 с.

8. Говорун Т.В. Гендерна психологія : навчальний посібник. Київ : Видавничий центр «Академія», 2004. $308 \mathrm{c}$.

9. Кравець В.П. Гендерна педагогіка : навчальний посібник. Тернопіль : Джура, 2003. 416 c

10. Гендерні стандарти сучасної освіти : збірка рекомендацій / ред. рада О.М. Кікінеджі, Т.О. Дороніна, О.Г. Біла. Запоріжжя : Друкарський світ, 2011. Ч. 3. 282 с.

\section{References}

1. Stoller R. (1968) Sex and Gender: On the Development of Masculinity and Femininity. New York.

2. Rich A. (1977) Of Women Born : Motherhood as Experience and Institution. London : Viagro.

3. Unger R. (1979) Toward a Redefinition of Sex and Gender. American Psychologist. No. 3. pp. 43-57.

4. Rubin G. (2000) Obmen Zhenschinami: Zametki o politichescoi economii pola [The Traffic in Women: Notes on the 'Political Economy' of Sex]. Khrestomatyja femynystskykh tekstov. Perevody. [Chrestomathy of feminist texts. Translations]. E. Zdravomyslova, A. Tiomkina (eds.). Saint Petersburg. «Dmytryj Bulanin». pp. 89-139 (in Russian).

5. On Education : Law of Ukraine of 05.09.2017 № 2145-VIII. Retrieved from: http://zakon.rada.gov.ua/ laws/show/2145-19/ (accessed 27 July 2020).

6. Nezhynska O.O. (2008) Model gendernoyi competenciyi kerivnykiv zahalnoosvitnih navchalnyh zakladiv. [Model of gender competence of managers of comprehensive educational establishments]. V.V. Oliynyk (Ed). Visnyk pisliadyplomnoyi osvity : Collection of scientific works. Kyiv. Vol. 10. pp. 212-219. 
7. Lytvyn A. (2014) Metodolohichni zasady poniattia "pedahohichni umovy": na dopomohu zdobuvacham naukovogo stupenia [Metodological basis of the «Pedagogical conditions» notion: in aid of scientific degree applicants]. Lviv : SPOLOM (in Ukrainian).

8. Govorun T.V. (2004) Genderna psyholohia: navch. posib. [Gender psychology: study guide]. Kyiv : «Academia» (in Ukrainian).

9. Kravets V. P. (2003) Genderna pedagogika : navch. posib. [Gender Pedagogic: study guide]. Ternopil : Dzhura (in Ukrainian).

10. Kikinetzhi O.M., Doronina T.O., Bila O.G. (eds.) (2011) Genderni standarty suchasnoyi osvity : zbirka recom. Ch.3. [Gender standards of modern education : recommendations collection. Part 3]. Zaporizhia: Drukarskyi svit (in Ukrainian). 